\title{
Relationship of education and socio-economic status with knowledge about abnormal uterine bleeding and its risk factors
}

\author{
Nupur Hooja*, Nisha Singh, Premlata Mital, Smriti Bhargava, Avantika Sharma, \\ Bhomraj Kumawat
}

Department of Obstetrics and Gynaecology, S.M.S. Medical College, Jaipur, Rajasthan, India

Received: 14 June 2016

Accepted: 04 July 2016

*Correspondence:

Dr. Nupur Hooja,

E-mail: nupurhooja@gmail.com

Copyright: ( ) the author(s), publisher and licensee Medip Academy. This is an open-access article distributed under the terms of the Creative Commons Attribution Non-Commercial License, which permits unrestricted non-commercial use, distribution, and reproduction in any medium, provided the original work is properly cited.

\begin{abstract}
Background: Abnormal uterine bleeding (AUB) is a common but overlooked condition. The lack of information and poor attitude towards health is often the reason. The knowledge of women regarding AUB and the preventable factors and its association with their education and socioeconomic status has never been assessed. Hence, the study was undertaken to assess the knowledge and attitude of women with AUB regarding the condition, its etiology, risk factors and treatment modalities in relation to their education and socio economic status.

Methods: The cross sectional descriptive study was carried out among women with AUB. Structured interviewer administered questionnaire was used to collect the required information. Knowledge of AUB and its risk factors from women with AUB were given scores 1-8 and 1-6 respectively. Information on education and socioeconomic status was also noted. Statistical analysis of data was done.

Results: Knowledge score for AUB $\leq 4$ and its risk factors $\leq 3$ was found in $63 \%$ and $72 \%$ of respondents respectively. Poor reading ability and low socio economic status was significantly associated with poor knowledge scores.

Conclusions: Intensive enlightenment of population using the mass media by trained personnel and strengthening of primary health care services is recommended.
\end{abstract}

Keywords: Knowledge, Socio-economic status, Education, Abnormal uterine bleeding

\section{INTRODUCTION}

One third of outpatient's visits to the gynaecologists are for abnormal uterine bleeding (AUB), and it accounts for more than $70 \%$ of all gynaecologic consults in the perimenopausal and postmenopausal years. ${ }^{1} \quad$ The International Federation of Gynaecology and Obstetrics (FIGO) has proposed a classification system for 9 major causes of AUB (PALMCOEIN). ${ }^{2}$ and the likely cause of abnormal uterine bleeding is usually related to age. Abnormal bleeding caused by hormone imbalance is more common in teenagers or in women who are approaching menopause. Obesity, PCOS, anorexia or crash diets, stress and extreme exercise account can all disrupt normal ovulatory function and may be considered as preventable risk factors for AUB. ${ }^{3}$ There has been a move to describe AUB in terms of its impact on a woman's physical, emotional, social and material quality of life (QOL).

Though few studies have been done to assess the burden of AUB on society however, the knowledge of women regarding various aspects of AUB and its association with their socio demographic status had never been assessed. Hence, the study was undertaken to assess the knowledge and attitude of women with AUB in relation to their education level and socio economic status.

\section{METHODS}

This was a cross sectional descriptive study carried out among women with AUB. Two hundred women with 
AUB were enrolled in the study. Written informed consent was taken of all participants.

Structured interviewer administered closed ended questionnaire was used to collect the required information. Knowledge about AUB and its risk factors were given scores 1-8 and 1-6 respectively. Education and socioeconomic status of respondents was noted. Updated BG Prasad socioeconomic classification, 2014 was used to record the socioeconomic status of women. ${ }^{4}$ Descriptive statistical analysis was done for all relevant data (Table 1 and 2).

Table 1: Questionnaire for score of knowledge about AUB.

\begin{tabular}{|lll|}
\hline Questionnaire for score of knowledge about AUB & Yes/No & Score \\
\hline AUB is a spiritual disease & No & 1 \\
\hline AUB is seen mostly in infertile women & No & 1 \\
\hline Sterilization always causes AUB & Yes & 1 \\
\hline Postcoital bleeding may occur in AUB & Yes & 1 \\
\hline AUB may be associated with vaginal discharge & Yes & 1 \\
\hline Medical treatment is helpful in AUB & No & 1 \\
\hline Hysterectomy is the only treatment of AUB & Total \\
\hline
\end{tabular}

Table 2: Questionnaire for score of knowledge about risk factors of AUB.

\begin{tabular}{|lll|}
\hline Questionnaire for score of knowledge about risk factors of AUB & Yes/No & Score \\
\hline Obesity is a risk factor of AUB & Yes & 1 \\
\hline Diabetes mellitus is a risk factor of AUB & Yes & 1 \\
\hline Having multiple sexual partners may be a risk factor for AUB & Yes & 1 \\
\hline Positive family history may be a risk factor for AUB & Yes & 1 \\
\hline Stress may be a risk factor for AUB & Yes & 1 \\
\hline Rigorous physical exercise/dieting may be a risk factor for AUB & Yes & 6 \\
\hline & Total \\
\hline
\end{tabular}

\section{Data analysis and processing}

All data thus collected was entered in Microsoft excel sheet and was subjected for statistical analysis. Quantitative data was summarized as mean and SD whereas qualitative data as percentage. Paired and unpaired " $\mathrm{t}$ " test was used for comparison of quantitative data. While 'Chi-square,' test was used for qualitative data. A p value less or equal to 0.05 was considered indicative of a significant factor effect.

\section{RESULTS}

The age of respondents ranged from 13 years to 47 years, $65 \%$ of them were in between 23 -37years (mean age $\pm \mathrm{SD}=29.705 \pm 7.852) .87 .5 \%$ of the respondents were married. $85 \%$ were multiparous (mean parity $\pm \mathrm{SD}=$ $2.33 \pm 171) .44 .5 \%$ were unemployed while only a small group $(9.5 \%)$ were professionals.

Education level of respondents also varied, with 3.5\% being postgraduates and $9 \%$ graduates. $19.5 \%$ of them were illiterate and $33.5 \%$ had primary school education. We found a significant association between education and their knowledge score, with the more educated being better informed, both about AUB as well as about its risk factors (Table 3 and 4).

Table 3: Association of education level and knowledge about AUB.

\begin{tabular}{|c|c|c|c|}
\hline Literacy status & \multicolumn{3}{|c|}{$\begin{array}{l}\text { Knowledge score of } \\
\text { AUB }\end{array}$} \\
\hline & $\leq 4$ & $>4$ & Chi square \\
\hline$\leq \operatorname{Primary}(\mathrm{n}=106)$ & 86 & 20 & test with \\
\hline$>$ Primary $(n=94)$ & 40 & 54 & D.F 1 \\
\hline Total $(n=200)$ & 126 & 74 & $\begin{array}{l}30.176 \\
\mathrm{P} \leq 0.0001 \\
\mathrm{HS}\end{array}$ \\
\hline
\end{tabular}

The result was significant at $\mathrm{P}<0.0001$.

Though respondents belonged to all economic backgrounds, $25.5 \%$ were from socio-economic class with per capita monthly income Rs. 2405 or less, $11 \%$ had Rs.736 or less. We also found a significant association between socio-economic status and their knowledge score, with the ones with more income being 
better informed, both about AUB and about its risk factors (Table 5 and 6).

Table 4: Association of education level and knowledge about risk factors of AUB.

\begin{tabular}{|c|c|c|c|}
\hline Literacy status & \multicolumn{3}{|c|}{$\begin{array}{l}\text { Knowledge of risk factors } \\
\text { score of AUB }\end{array}$} \\
\hline & $\leq 3$ & $>3$ & Chi square \\
\hline$\leq$ Primary $(n=106)$ & 96 & 10 & test D.F 1 \\
\hline$>$ Primary $(n=94)$ & 48 & 46 & 36.627 \\
\hline Total $(n=200)$ & 144 & 56 & $\begin{array}{l}\mathrm{P} \leq 0.0001 \\
\mathrm{HS}\end{array}$ \\
\hline
\end{tabular}

The result was significant at $\mathrm{P}<0.0001$.

Table 5: Association of socioeconomic status and knowledge about AUB.

\begin{tabular}{|c|c|c|c|}
\hline $\begin{array}{l}\text { SocioEco.class } \\
\text { (modified } \\
\text { Prasad) }\end{array}$ & \multicolumn{3}{|c|}{ Knowledge score of AUB } \\
\hline $\begin{array}{l}\text { Per capita } \\
\text { monthly } \\
\text { income }\end{array}$ & $\leq 4$ & $>4$ & $\begin{array}{l}\text { Chi square test } \\
\text { D.F } 1 \quad 55.296\end{array}$ \\
\hline $\begin{array}{l}>\text { Rs.2405 } \\
(149)\end{array}$ & 116 & 33 & $\mathrm{P}=<0.0001 \mathrm{HS}$ \\
\hline$\leq$ Rs.2405 (51) & 10 & 41 & \\
\hline Total(200) & 126 & 74 & \\
\hline
\end{tabular}

The result was significant at $\mathrm{P}<0.001$.

Table 6: Association of socioeconomic status and knowledge about risk factors of AUB.

\begin{tabular}{|c|c|c|c|}
\hline $\begin{array}{l}\text { SocioEco class } \\
\text { (modified } \\
\text { Prasad) }\end{array}$ & \multicolumn{3}{|c|}{$\begin{array}{l}\text { Knowledge of risk factors score of } \\
\text { AUB }\end{array}$} \\
\hline $\begin{array}{l}\text { Per capita } \\
\text { monthly income }\end{array}$ & $\leq 3$ & $>3$ & $\begin{array}{l}\text { Chi square } \\
\text { test D.F } 1\end{array}$ \\
\hline >Rs.2405 (149) & 124 & 25 & \multirow{3}{*}{$\begin{array}{l}36.496 \\
\mathrm{P} \leq 0.001 \\
\mathrm{HS}\end{array}$} \\
\hline$\leq$ Rs.2405 (51) & 20 & 31 & \\
\hline Total (200) & 144 & 56 & \\
\hline
\end{tabular}

The result was significant at $\mathrm{P}<0.001$.

\section{DISCUSSION}

Literacy can be defined as an individual's ability to read, write, speak and compute and solve problems necessary to function at the job and in society, to achieve one's goals, and to develop one's knowledge and potential. ${ }^{5}$ Literacy sometimes describes a person's knowledge about a particular topic [e.g., computer literacy]. Health literacy is a constellation of skills that constitute the ability to perform basic reading and numerical tasks for functioning in the health care environment and acting on health care information. ${ }^{6}$ Low health literacy may impair functioning in the health care environment, affect patientphysician communication dynamics, and inadvertently lead to substandard medical care. ${ }^{7}$ It is associated with poor understanding of written or spoken medical advice, adverse health outcomes, and negative effects on the health of the population. ${ }^{8}$ Certain groups have an especially high prevalence of low health literacy. They include people who completed fewer years of education, elderly ${ }^{9}$ and persons with lower cognitive ability. ${ }^{10}$ Other factors associated with lower literacy are income status classified as poor or near poor.

In this present study, the relationship of education level and socio-economic status of women with AUB and their knowledge regarding AUB and its risk factors was assessed. It showed women had little knowledge about AUB and its risk factors with high level of misconceptions about its etiology and treatment modalities. Poor literacy and low socio economic status was significantly associated with poor knowledge scores.

Quinlan et al reported that health knowledge was independently associated with education, income, and age. ${ }^{11}$ Walker and colleagues found health literacy to be significant and positively associated with health knowledge. ${ }^{12}$ Lack of knowledge left patients unable to recognize and respond to adverse side effects as reported by Davis et al. ${ }^{13}$

US Department of Health and Human Services searched several databases. According to this survey, many studies measured the relationship between literacy levels and knowledge of the use of health care services: Mammography, Cervical cancer screening, Emergency department discharge instructions, Heart Health Knowledge and informed consent, all of these demonstrated a statistically significant association between higher literacy level and knowledge of matters relating to use of these health services. Studies showed that various media which are understood even by the less read like educational videotapes and illustrated materials enhance the health knowledge more than print versions. ${ }^{14}$

\section{CONCLUSION}

Women with AUB presenting to the hospital were mostly unemployed females having primary schooling from middle and lower economic strata mostly in age group of 23-37 years. This study showed that low reading skill and poor health were clearly related.

It is therefore recommended that intensive public awareness campaigns about the etiology and modality of treatment of the condition should be done through use of radio, television, street plays and public camps besides the print media for the literate masses. Health care professionals should actively be involved in this initiative.

Reducing literacy-related barriers would go a long way in quelling the various misconceptions about AUB among the population and also encourage early presentation and hence prevent complications of AUB. 
Funding: No funding sources

Conflict of interest: None declared

Ethical approval: Not required

\section{REFERENCES}

1. Diagnosis of abnormal uterine bleeding in reproductive-aged women. Practice Bulletin No. 128. American College of Obstetricians and Gynecologists. Obstet Gynecol. 2012;120:197-206.

2. Munro MG, Critchley HO, Broder MS, Fraser IS. FIGO classification system (PALM-COEIN) for causes of abnormal uterine bleeding in nongravid women of reproductive age. FIGO Working group on Menstrual Disorders. Int J Gynaecol Obstet. 2011;113:3-13.

3. Abnormal Uterine Bleeding in Pre-Menopausal Women. SOGC Clinical Practice Guideline Journal of Obstetrics and Gynaecology Canada. 2013;35(5):292.

4. Mangal A, Kumar V, Panesar S, Talwar R, Raut D, Singh S. Updated BG Prasad socioeconomic classification, 2014: a commentary. Indian J Public Health. 2015;59:42-4.

5. National Literacy Act of 1991. Pub. L. No. 102-73, 105 Stat. 333. 1991:102-73.

6. American Medical Association. Ad Hoc Committee on Health Literacy for the Council on Scientific Affairs. JAMA. 1999;281:552-7.

7. Schillinger D, Piette J, Grumbach K. Closing the loop: physician communication with diabetic patients who have low health literacy. Arch Int Med. 2003;163(1):83-90.

8. Gazmararian JA, Baker DW, Williams MV. Health literacy among Medicare enrolees in a managed care organization. JAMA. 1999;281(6):545-51.
9. Kirsch I, Jungeblut A, Jenkins L. Adult literacy in America: A first look at the findings of the National Adult Literacy Survey. $3^{\text {rd }}$ edition. Washington, D.C.: National Center for Education, U.S. Department of Education, 2002;201.

10. Baker DW, Gazmararian JA, Sudano J. The association between age and health literacy among elderly persons. J Gerontol Series B-Psychol Scien Soc Scien. 2000;55(6]):S368-74.

11. Quilnan P, Kwanza O. Price,Steven K. Magid, Stephen Lyman, Lisa A, PatriciaWS. The relationship among health literacy, health knowledge, and adherence to treatment in patients with rheumatoid arthritis HSS J. 2013;9(1):42-9.

12. Walker D, Adebajo A, Heslop P, Hill J, Firth J, Bishop $\mathrm{P}$, et al. Patient education in rheumatoid arthritis: The effectiveness of the ARC booklet and the mind map. Rheumatology. 2007;46(10):1593-6.

13. Davis TC, Wolf MS, Bass PF, 3rd, et al. Low literacy impairs comprehension of prescription drug warning labels. J Gen Intern Med. 2006;21(8):84751.

14. Literacy and Health Outcomes U.S. Department Of Health And Human Services • Public Health Service Evidence Report/Technology Assessment: Number 87 AHRQ Available at:https://archive.ahrq.gov/ clinic/eptacarch.htm.

Cite this article as: Hooja N, Singh N, Mital PL, Bhargava S, Sharma A, Kumawat B. Relationship of education and socio-economic status with knowledge about abnormal uterine bleeding and its risk factors. Int J Community Med Public Health 2016;3:2229-32. 